\title{
Estimation of Groundwater Recharge Using GIS Method: A Case Study of Makotopong Village-Polokwane, South Africa
}

\author{
S. J. Tleane, J. M. Ndambuki \\ Department of Civil Engineering, Tshwane University of Technology, Pretoria, South Africa \\ Email: MabenaGO@tut.ac.za
}

How to cite this paper: Tleane, S.J. and Ndambuki, J.M. (2020) Estimation of Groundwater Recharge Using GIS Method: A Case Study of Makotopong VillagePolokwane, South Africa. Journal of Water Resource and Protection, 12, 985-1000. https://doi.org/10.4236/jwarp.2020.1211059

Received: September 25, 2020

Accepted: November 27, 2020

Published: November 30, 2020

Copyright $\odot 2020$ by author(s) and Scientific Research Publishing Inc. This work is licensed under the Creative Commons Attribution International License (CC BY 4.0).

http://creativecommons.org/licenses/by/4.0/

(c) (i) Open Access

\begin{abstract}
South Africa is a relatively dry country, with most rural areas experiencing high demand for water supply. Groundwater is one of the best alternative sources that can be used to augment the demand. However, this cannot sustainably be achieved unless accurate prediction of recharge to the groundwater aquifer is done. The objective of the study was to accurately estimate the groundwater recharge using ArcGIS method with a view of ensuring adequate groundwater for water supply exploitation. The study was conducted in Makotopong village in Polokwane. Data used in the study were sourced from diverse governmental agencies. Borehole logs were obtained from National Groundwater Archives. Geological and hydrogeological data were obtained from Council for Geoscience. All captured data were analysed to show the rainfall variations and estimation of groundwater recharge in different years. Groundwater recharge was estimated using ArcGIS 10.5. The simulated annual groundwater recharge varied from $0 \mathrm{~mm}$ to $51 \mathrm{~mm}$ with a mean recharge value of $12.04 \mathrm{~mm} / \mathrm{yr}$. The estimation of groundwater recharge using GIS methods resulted in a mean recharge value of $12.04 \mathrm{~mm} /$ year which shows a close comparison with previous studies conducted using Chlorine Mass Balance (CMB) and Water-Table Fluctuation (WTF). This implies that GIS is a potential tool that can be used to estimate groundwater recharge. It is recommended that GIS Method of estimating recharge be used in designing optimal sustainable groundwater supply systems.
\end{abstract}

\section{Keywords}

Groundwater, Recharge, ArcGIS

\section{Introduction}

Groundwater is one of the best alternative sources that can be used to augment 
the high water demand in various areas either rural or urban. Groundwater is widely used for irrigation and rural water supply. Global water demand is largely influenced by population growth, urbanization, food, and energy security policies, and macroeconomic processes such as trade globalization and changing consumption patterns. [1] reported that groundwater is found to be the best possible source of drinking water, especially in rural areas where most disadvantaged people live. Groundwater is also considered by municipalities in some urban areas in order to supplement municipal water supply for domestic use. Domestic water use has increased drastically in the past years, however accessible freshwater resources remain limited. [2] reported that groundwater is a precious resource of limited extent. Sourcing groundwater for water supply can be met most cost-effectively. However, to ensure that such groundwater supplies are sustainable, it is imperative that accurate prediction of recharge to the groundwater aquifer is done.

Estimation of groundwater recharge has escalated from a basic problem to an urgent and major issue in hydrogeologic research for sustainable development of groundwater [3]. According to [4], estimation of groundwater recharge is key to the accurate determination of available groundwater. A very important parameter which aids in the accurate determination of the quantity of water available in a groundwater aquifer is recharge. Groundwater recharge informs on the amount of groundwater that can be exploited without mining the aquifer (sustainable exploitation of groundwater). For this reason, there is a need to quantify groundwater recharge with a view to estimating the groundwater storage with a high degree of accuracy.

Estimation of groundwater recharge can be done using various methods such as Water-Table Fluctuation (WTF) and Chlorine mass balance (CMB) methods depending on the availability of data. This refers to methods that can handle spatial variability. Geographic information systems (GIS) have emerged as effective tools for handling spatial data and decision making in several areas including engineering, geology and environmental fields. The emergence of GIS method has brought with it innovative approaches of quantifying climatic parameters more accurately.

[5] used Chlorine mass balance (CMB) method to estimate groundwater recharge response from rainfall events in a semi-arid fractured aquifer in Limpopo Province. Estimated local recharge using CMB method ranged from 0.24 to 8.8 $\mathrm{mm} / \mathrm{a}(0.04 \%-1.3 \%$ mean annual precipitation (MAP)). [5] used ArcGIS to generate groundwater recharge distribution maps from the estimated recharge results. The results expanded knowledge on the nature of groundwater recharge response from rainfall in fractured aquifers in semi-arid areas and the applicability of CMB method in recharge estimation.

[6] carried out a study to identify the artificial groundwater recharge zones in Bist Doab basin of Indian Punjab using remote sensing and geographical information system (GIS) for augmenting groundwater resources. The study area has been facing severe water scarcity due to intensive agriculture for years. The re- 
charge map was generated and was divided into four zones (poor, moderate, good, and very good) based on their influence on groundwater recharge [6].

The purpose of this paper is to demonstrate how accurately groundwater recharge can be estimated using the Geographic Information System (GIS) method with a view of ensuring adequate groundwater for water supply exploitation. From an economic point of view, Makotopong village cannot be fed through the traditional water supply system and hence understanding and repositioning their groundwater dependency becomes imperative.

\section{Summary}

The main objective of this study is to estimate the groundwater recharge of Makotopong village Polokwane in South Africa by using GIS method. From the borehole logs, geological and hydrogeological data, spatial layers of the groundwater head elevation, porosity, transmissivity and saturated thickness were generated to constitute a database. These layers, integrated into the ArcGIS software, were used to assess the recharge and generate the recharge potential map. The estimation of groundwater recharge was computed using Darcy flow tool in ArcGIS. The simulated annual groundwater recharge varied from $0 \mathrm{~mm} / \mathrm{yr}$ to 51 $\mathrm{mm} / \mathrm{yr}$. The annual average recharge is estimated at $12.04 \mathrm{~mm} / \mathrm{year}$, close to the values estimated using Chlorine Mas Balance (CMB) and Water-Table Fluctuation methods. The recharge potential map is a decision-making tool for prospecting groundwater. GIS is a powerful tool that can be used to estimate groundwater recharge.

\section{Materials and Methods}

\subsection{Description of Study Area}

The study area (Makotopong village) is situated in the central part of Limpopo province and it falls under Mothapo cluster which is located in the north-eastern part of Polokwane Local Municipality (PLM). The study area is bordered by two tributaries at the southern side of Sandriver, the Diepriver tributary at the western side and by the non-perennial Turfloop tributary at the eastern side downstream of the Turfloop Dam located at the border of the Sebayeng and Badimong cluster. The area falls within the Pietersburg Plateau. The climate is cooler with mild to warm summers and cool winters with some frost occurrence. The maximum temperature is between $26^{\circ} \mathrm{C}-28^{\circ} \mathrm{C}$ with the hottest month of the year being January. The minimum temperature is between $4^{\circ} \mathrm{C}-6^{\circ} \mathrm{C}$ with the coolest month of the year being July. According to South African Weather Services [7], rainfall is between 400 and $600 \mathrm{~mm}$ per annum but tends to be reliable although usually concentrated over a short period in the year.

The area of study was found suitable because 1) it falls within groundwater target areas, 2) the community in the area is currently supplied with water pumped from the ground and 3) the availability of the data. The area is falls under latitude $-23^{\circ} 38^{\prime} 0^{\prime \prime S}, 29^{\circ} 33^{\prime} 0^{\prime \prime} \mathrm{E}$ and $-23^{\circ} 54^{\prime} 30^{\prime \prime} \mathrm{S}, 29^{\circ} 49^{\prime} 30^{\prime \prime} \mathrm{E}$ (Geographic (Lat/Lon)) WGS_1984. The study area is shown in Figure 1. 


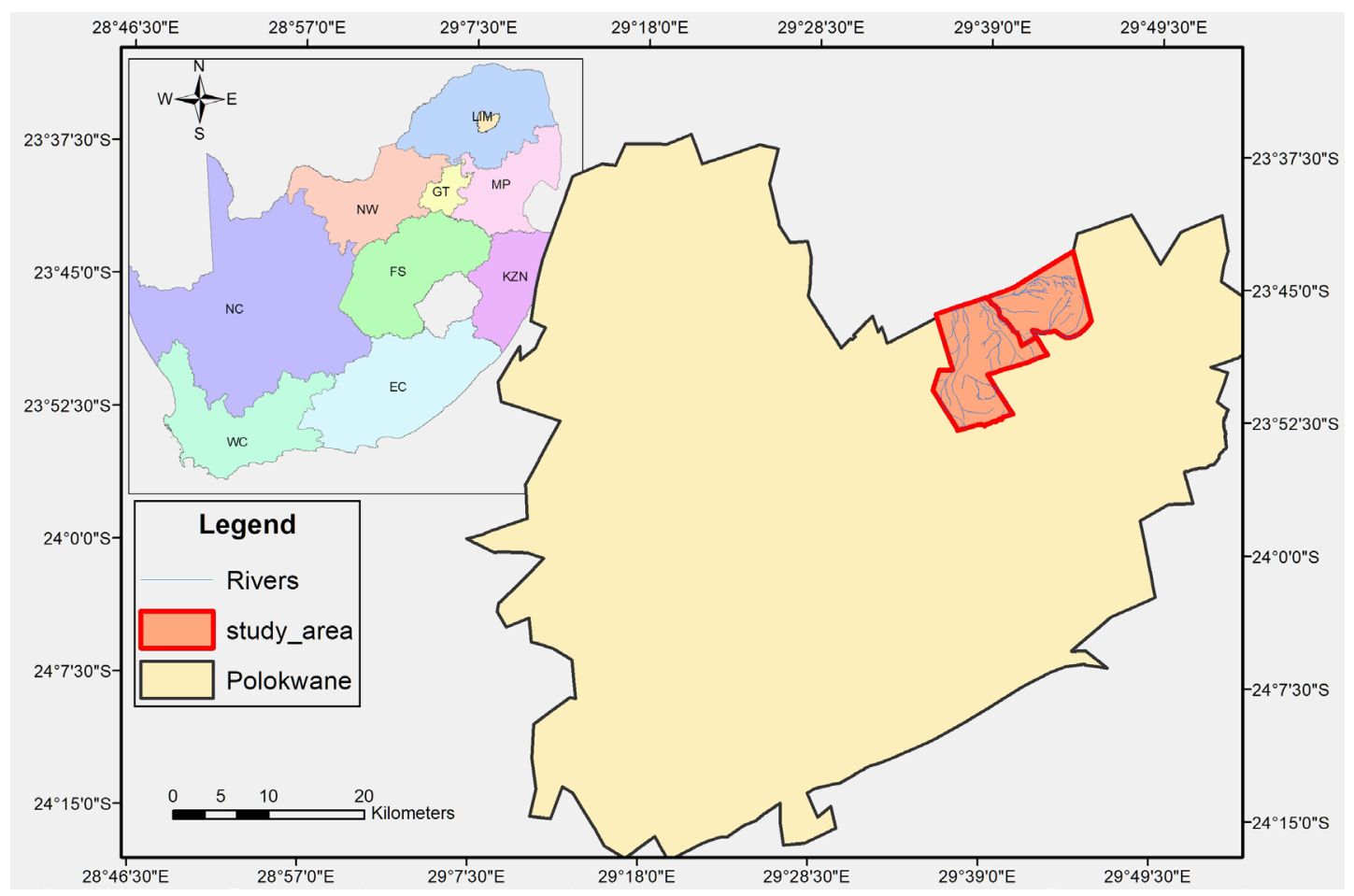

Figure 1. Map of study area-Polokwane.

\subsection{Data Collection}

\subsubsection{Geology}

The geological data was obtained from Council for Geoscience in Pretoria offices. The geological structures found in the study area which are (faults, fractures and lithological contacts) have more effect on the movement as well as occurrence of groundwater. The geology of the study area predominantly consists of the Goutplaats-Hout River Gneiss, (Zgo) thus resulting in generally high groundwater potential. The presences of numerous pegmatites, which appear at different levels to relatively great depths, seem to contribute substantially to the high groundwater potential of these units. The underlying geology consists of medium-grained, yellowish, laminated sandstone. Dykes diabase found in the study area act as a barrier for groundwater abstraction. Figure 2 shows the geology of the study area.

\subsubsection{Soils Type}

The soil data including soil map in a form of shapefiles were obtained from Food and Agriculture Organization-UNESCO [8] database. The shapefile contains attributes like 1) soil type 2) soil texture 3) Hydrological Soil Group (HSG) and 4) soil polygon area. ArcGIS was used to extract the subset of soil map of the study area from FAO soil map. The large part of the study area is comprised of sandy clay loam soil and the smaller portion of the study area is comprised of sandy loam type of soil. Figure 3 shows the soil type of the study area. Soil type of the study area is required as it gives guidance on the amount of pores for water infiltration to the aquifer. 


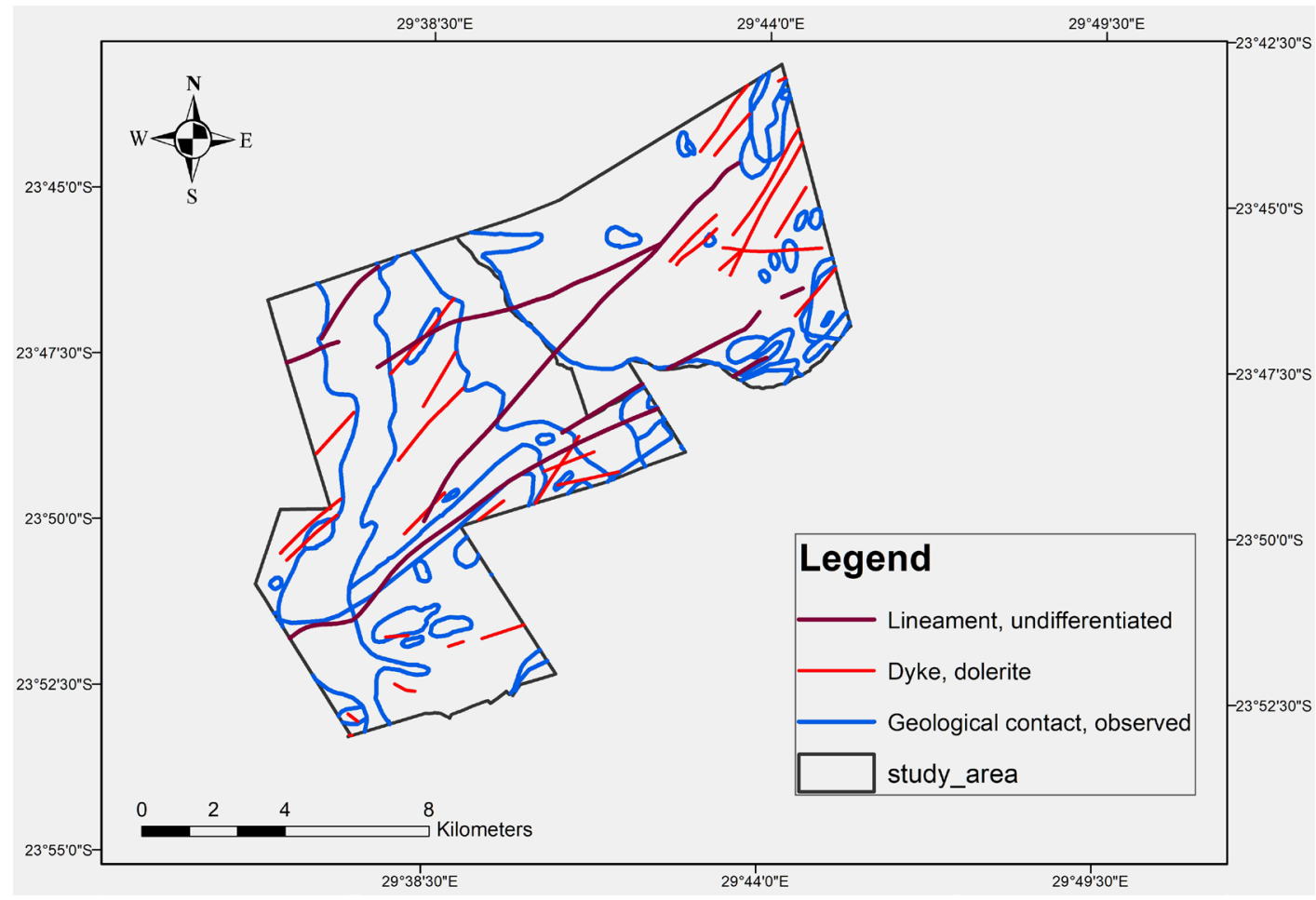

Figure 2. Geology map of Makotopong village.

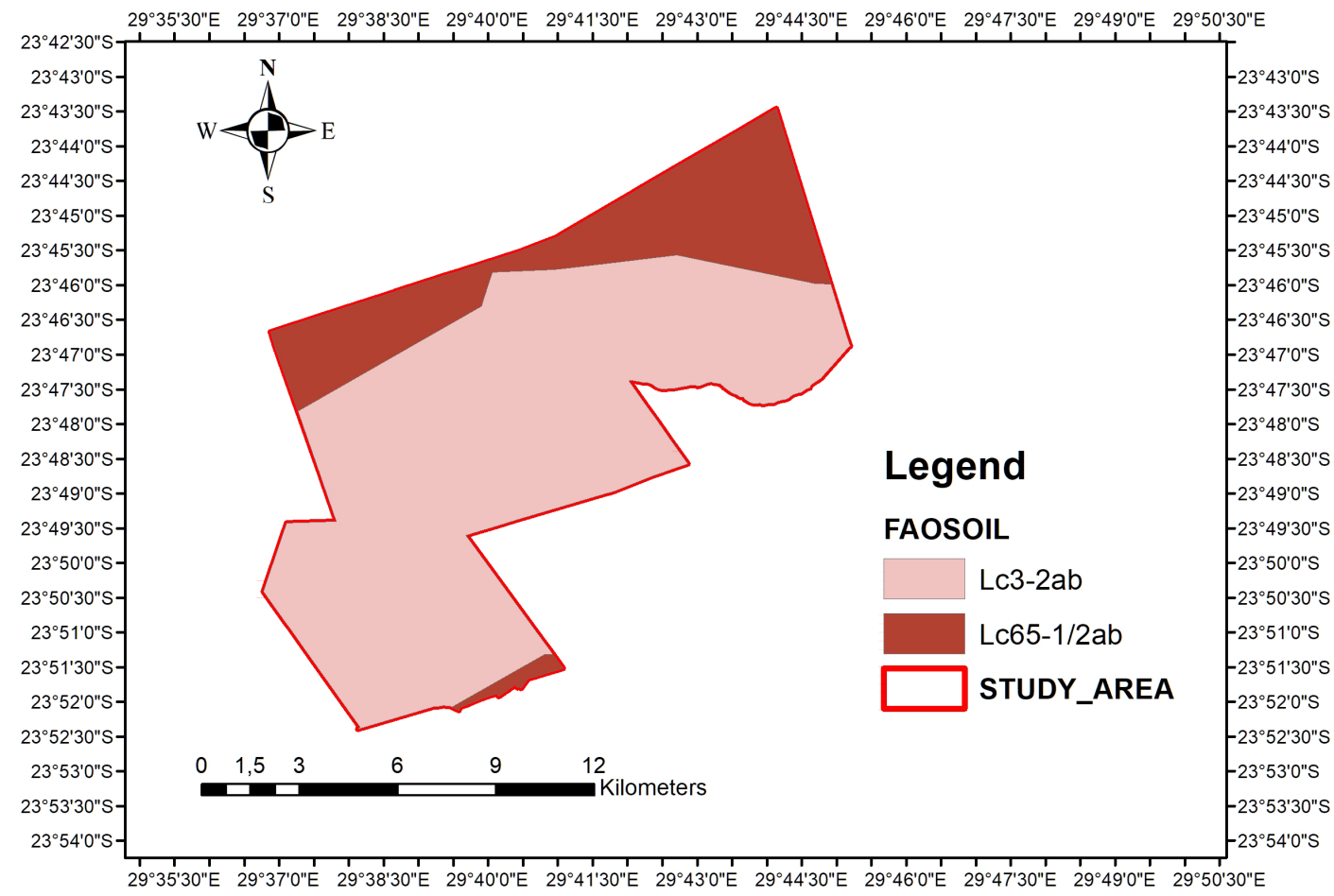

Figure 3. Soil map of Makotopong village.

\subsection{Methodology}

\subsubsection{Theoretical Framework for Recharge Estimation}

This section entails the method used in the implementation of the study. The 
overall objective was to estimate the groundwater recharge of the study area using GIS tools.

Geographic Information System (GIS) and Visual Modflow software were used. GIS is a globally used software. The GIS approach correlates various layers to recharge probability. The layers are then integrated to generate a recharge potential map. This method that is used to determine potential recharge areas using available spatial data in a GIS database is similar to the DRASTIC approach developed for aquifer vulnerability [9]. Unlike conventional methods, GIS methods can take into account the diversity of factors that control groundwater recharge. After estimation of groundwater using GIS method, the next step was to analyse the results using Visual MODLFOW-2003. In order to analyse the collected data, it was essential to have a validated and reliable instrument to capture the collected data.

The estimation of groundwater recharge was computed using Darcy flow tool in ArcGIS. The determination of Darcy flow examination was double. First, it was used to check the reliability of groundwater datasets and to create raster pictures of groundwater flow paths (ArcGIS, 2011). The standard production raster is the groundwater volume balance residual raster, which procedures the difference between the flow of water into and out of each cell. The recharge value determined from the ArcGIS methods was computed from the data in a well using the Darcy Law [10]:

$$
Q=k_{v} A \frac{\mathrm{d} h_{t}}{\mathrm{~d} x}
$$

where $Q$ is discharge, $k_{v}$ is the hydraulic conductivity, $A$ is area of flow and $\mathrm{d} h_{t} / \mathrm{d} x$ is the gradient of pressure or head. To apply GIS method hydraulic conductivity, water level and water strike levels are required.

\subsubsection{Data Requirement}

In this case, methods that use field measurements were proposed (water level, water strike level and Geological data), which is a variant of the water table response to recharge event approach. Collected data was prepared on an Excel spreadsheet. Numerous stages were carried out for grounding of input data for GIS model which includes grounding of (groundwater head elevation maps, porosity map, transmissivity map, and saturated thickness map). Table 1 lists the datasets and their formats required by ArcGIS. The extent of modelling area is defined by an aquifer layer in the format of ArcGIS raster.

\subsubsection{Assigning Model Elevations}

Model elevations were assigned and defined as follows:

The top layer of the model was specified as the natural ground surface. The natural ground surface was determined from the topographical map and was converted to an excel spreadsheet and then imported into Visual MODFLOW. The natural ground surface dataset of South Africa was acquired from Council for Geoscience, Pretoria. Natural ground surface was sorted out to formulate 
Table 1. GIS input parameters.

\begin{tabular}{clc}
\hline Parameters & \multicolumn{1}{c}{ Explanation } & Data Type \\
\hline Head elevation & $\begin{array}{l}\text { The raster data where each cell value denotes the groundwater } \\
\text { head elevation at that position. The head is normally an } \\
\text { elevation above some reference level, such as mean sea level. }\end{array}$ & Raster Sheet \\
& $\begin{array}{l}\text { The raster data where each cell value denotes the actual } \\
\text { creation porosity at that position. The volume of the porous } \\
\text { Porosity }\end{array}$ & Raster Sheet \\
& $\begin{array}{l}\text { The raster data where each cell value denotes the waterlogged } \\
\text { depth at that position. The value for the depth is taken from } \\
\text { Saturated thickness } \\
\end{array}$ & geological properties of the aquifer. The saturated thickness \\
gives an indication of the aquifer depth. & Raster Sheet \\
& $\begin{array}{l}\text { The raster data where each cell value symbolizes the creation } \\
\text { transmissivity at that position. Transmissivity has effect on } \\
\text { groundwater recharge rate because water permeates between } \\
\text { Transmissivity }\end{array}$ & Raster Sheet \\
& granular void or pore spaces, and fractures between rocks & \\
\hline
\end{tabular}

topographic and slope maps of the study area. A gradient grid map was created from elevation map through a surface function in spatial analyst tool by using ArcGIS. Both the grid maps were transformed to ASCII files and used in the GIS model.

Groundwater levels from the monitoring wells were first arranged properly on an excel spreadsheet and then imported into Visual MODFLOW. Well, pumping rates were defined on the model and assigned values as collected from the study area and secondary sources.

\subsubsection{Wells}

Collected borehole data, such as groundwater levels and pumping rates were used for model inputs. Data was captured on excel spreadsheet and processed on ArcGIS to be saved as shapefiles since Visual MODFLOW is able to read GIS shapefiles.

Pumping rates were captured on the model and the borehole information was used to create water levels during pumping as drawdowns. Data processing was done using ArcGIS and saved as shapefiles and then later imported to Visual MODFLOW through import tool.

\section{Results and Discussions}

Figure 4 shows the groundwater head elevation raster measured in meters below ground level (mbgl). Kriging tool is one of the ArcGIS tools that are used to generate an estimated surface from a scattered set of points with $\mathrm{z}$-values. In this case, head elevations were interpolated using Kriging tool. The groundwater level varied between 1123 and 1273 .

Figure 5 shows the porosity of the study area with the values ranging between $0.004 \%$ and $0.044 \%$. The operational porosity field, physical things of the aquifer, was projected from geological information. Porosity is demarcated as the 


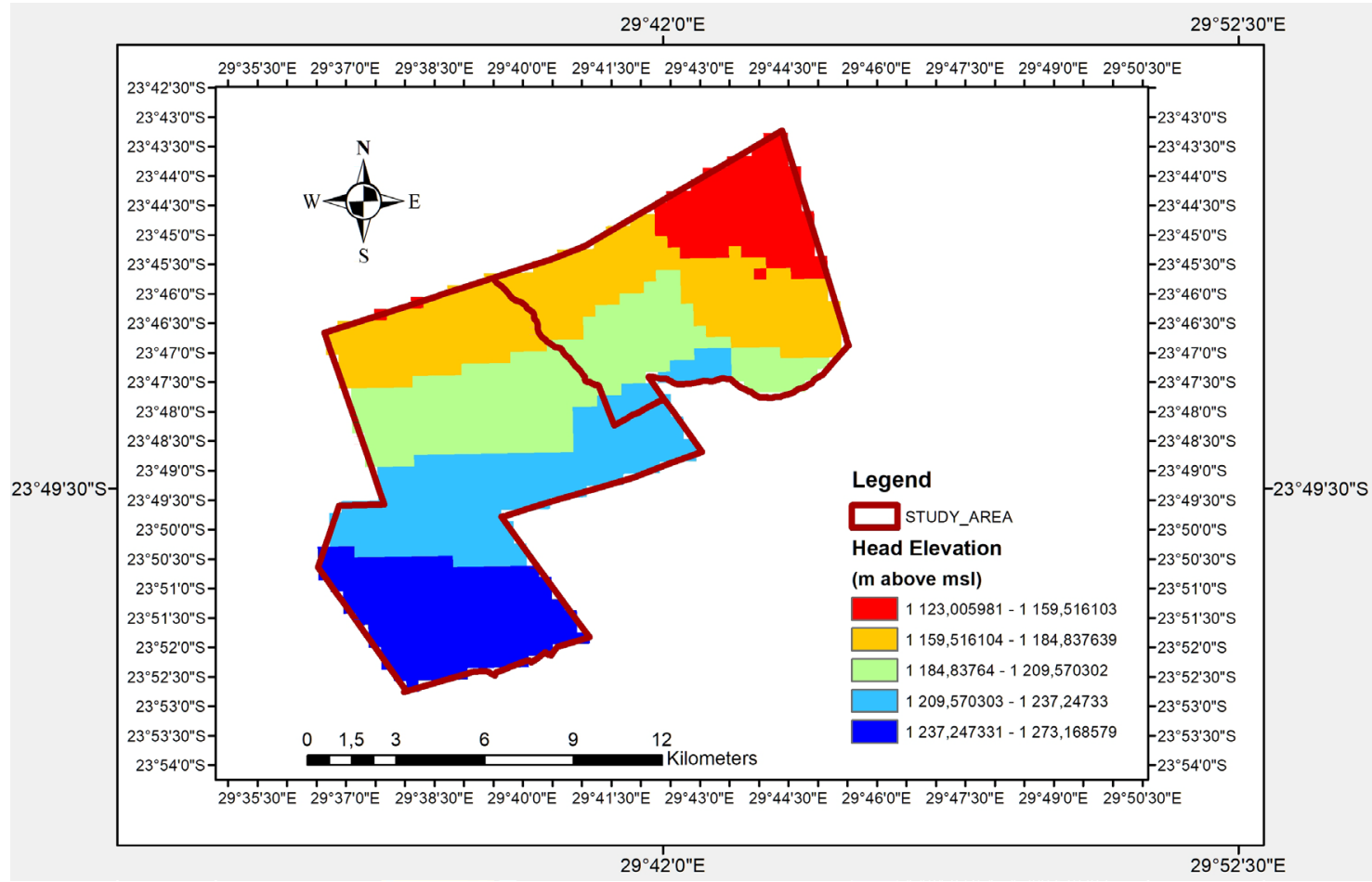

Figure 4. Head Elevation map.

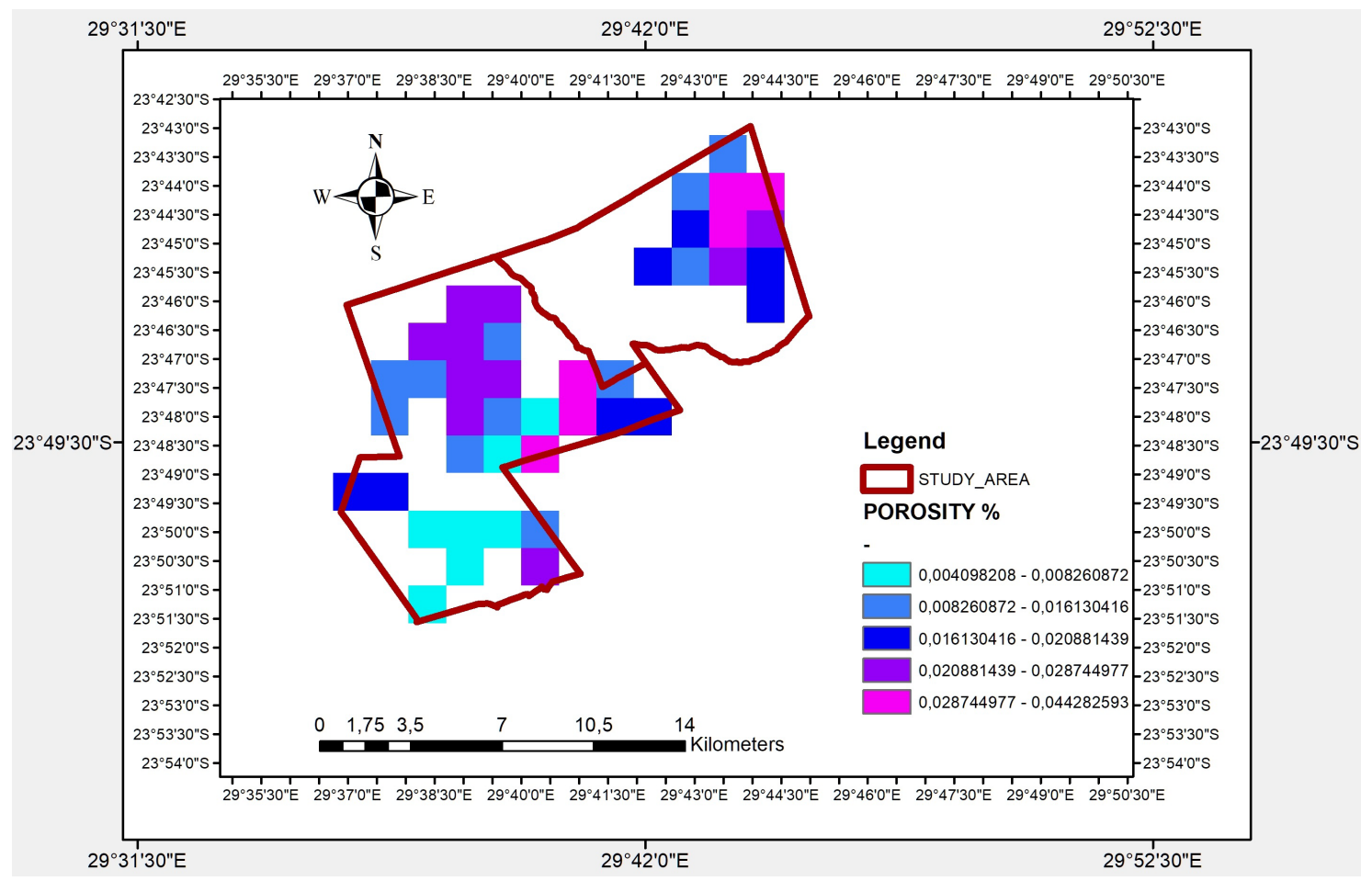

Figure 5. Porosity map.

size of void space between soils particles that pays to liquid flow distributed by the total volume. The porosity values were used to calculate the groundwater recharge using Darcy law in GIS environment. From the porosity analysis, the 
study area shows virtuous infiltration of groundwater into the aquifer, which means the geological structure of the study area is suitable for groundwater storage.

Figure 6 shows the transmissivity values of the study area ranging between $2.48 \mathrm{~m} /$ day and $268.502 \mathrm{~m} /$ day. The transmissivity of an aquifer is demarcated as the hydraulic conductivity $\mathrm{K}$ multiply by the soaked aquifer depth $\mathrm{b}$, as units of span squared over a period. The property was assessed from geological information of the area. The captured data for lithological logs was adjusted against the transmissivity measurements. Hydraulic conductivity has effects on groundwater recharge rate because water permeates between granular void and fractures between rocks. The larger the pore space, the more permeable the material.

Figure 7 shows the saturated thickness map of the study area ranging from a depth of $57.069 \mathrm{~m}$ to $91.392 \mathrm{~m}$. The aquifer depth values were used as aquifer thickness to calculate the groundwater recharge using Darcy law in ArcGIS tools. The aquifer thickness ranged between a depth of $23.148 \mathrm{~m}$ and $91.392 \mathrm{~m}$. The aquifer thickness analysis shows that the drilling of new boreholes in the study area can only go to a maximum depth of $91.392 \mathrm{~m}$.

The thematic layers were integrated into ArcGIS for delineation of groundwater recharge area. The layers were then integrated to generate a recharge potential map.

In this case, the groundwater recharge was estimated using ArcGIS 10.5. The simulated annual groundwater recharge varied from $0 \mathrm{~mm} / \mathrm{yr}$ to $51 \mathrm{~mm} / \mathrm{yr}$ with a mean average recharge value of $12.04 \mathrm{~mm} / \mathrm{yr}$. Figure 8 shows the output volume

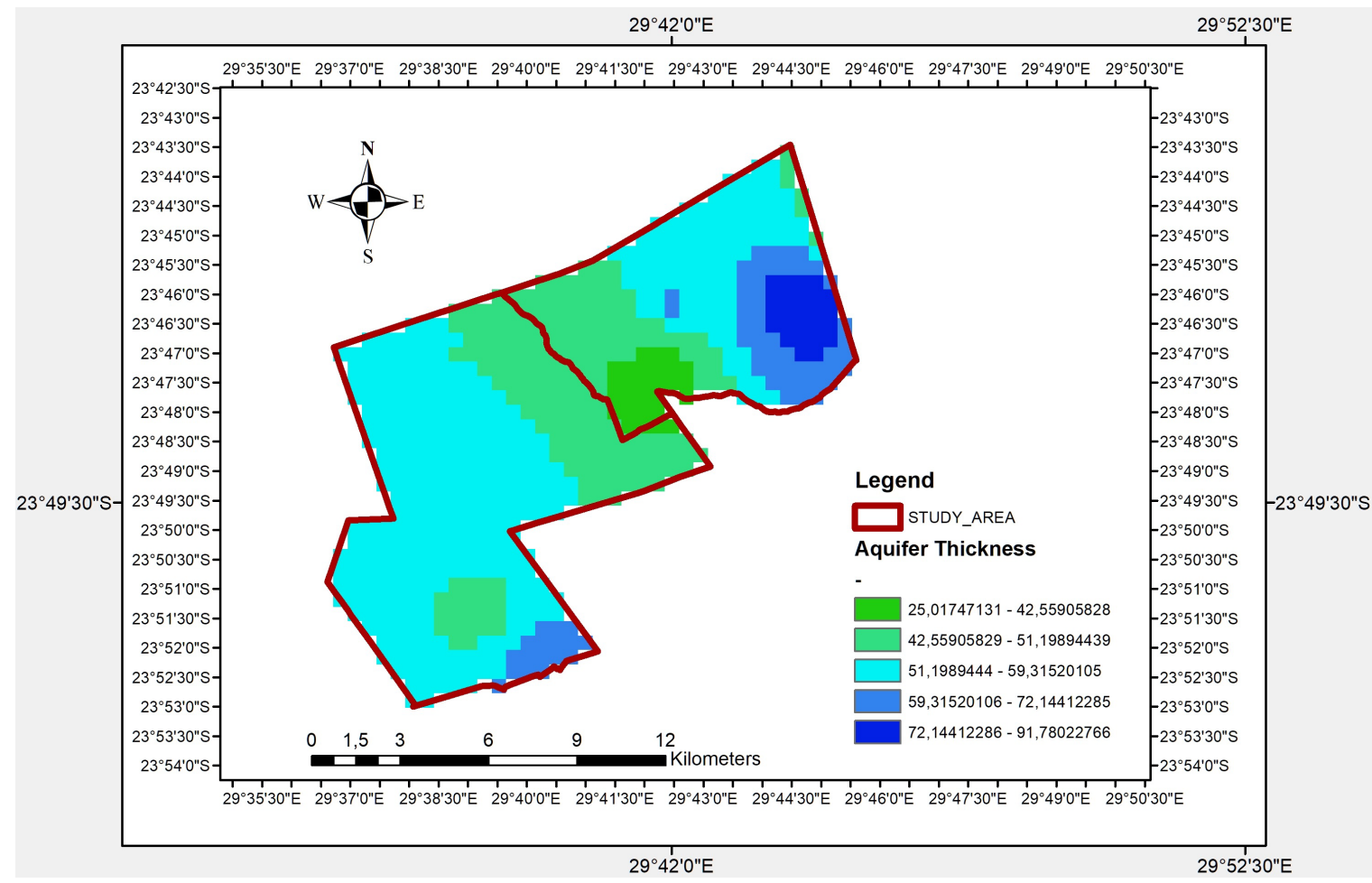

Figure 6. Transmissivity map. 


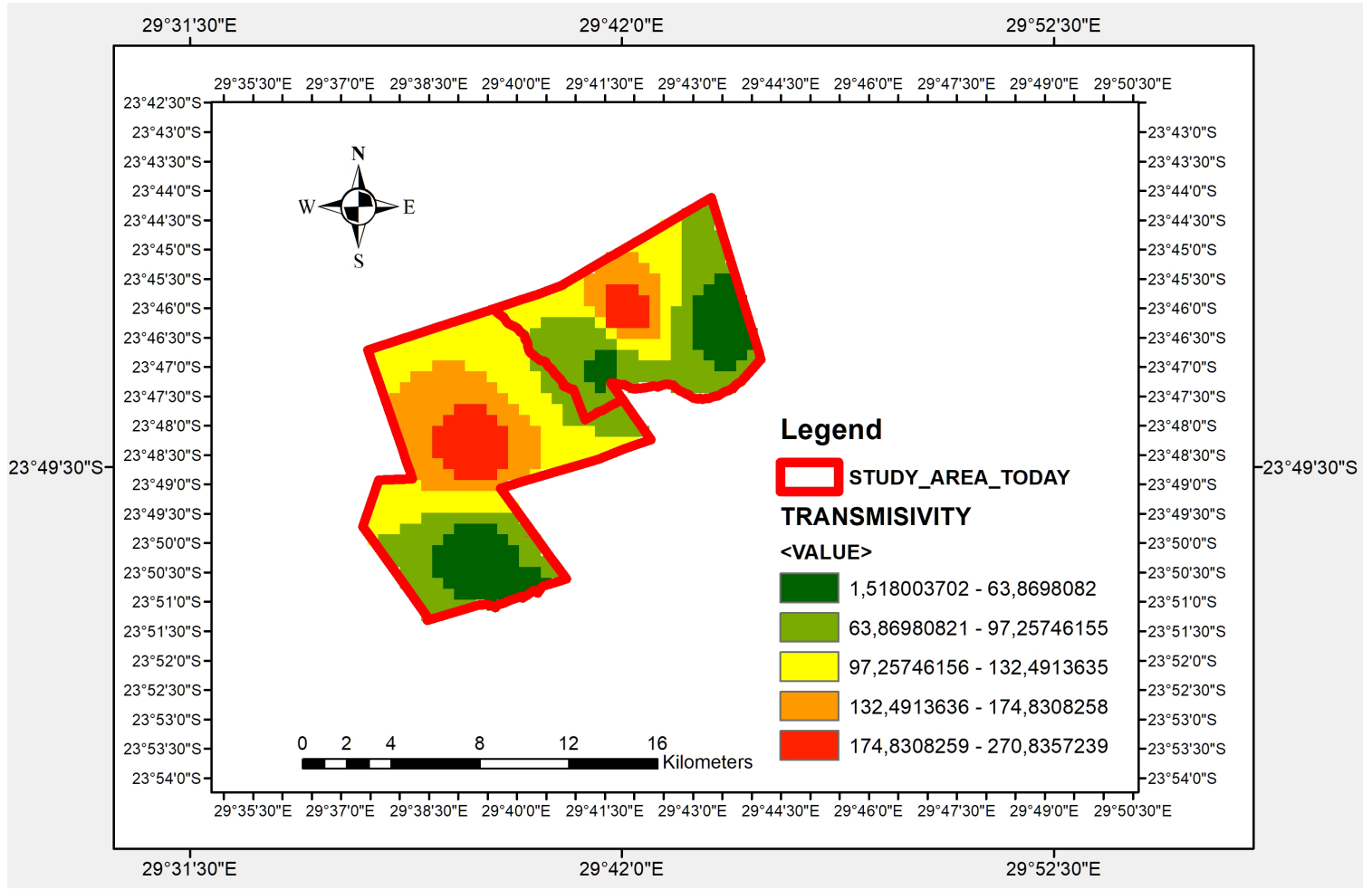

Figure 7. Aquifer saturated thickness map.

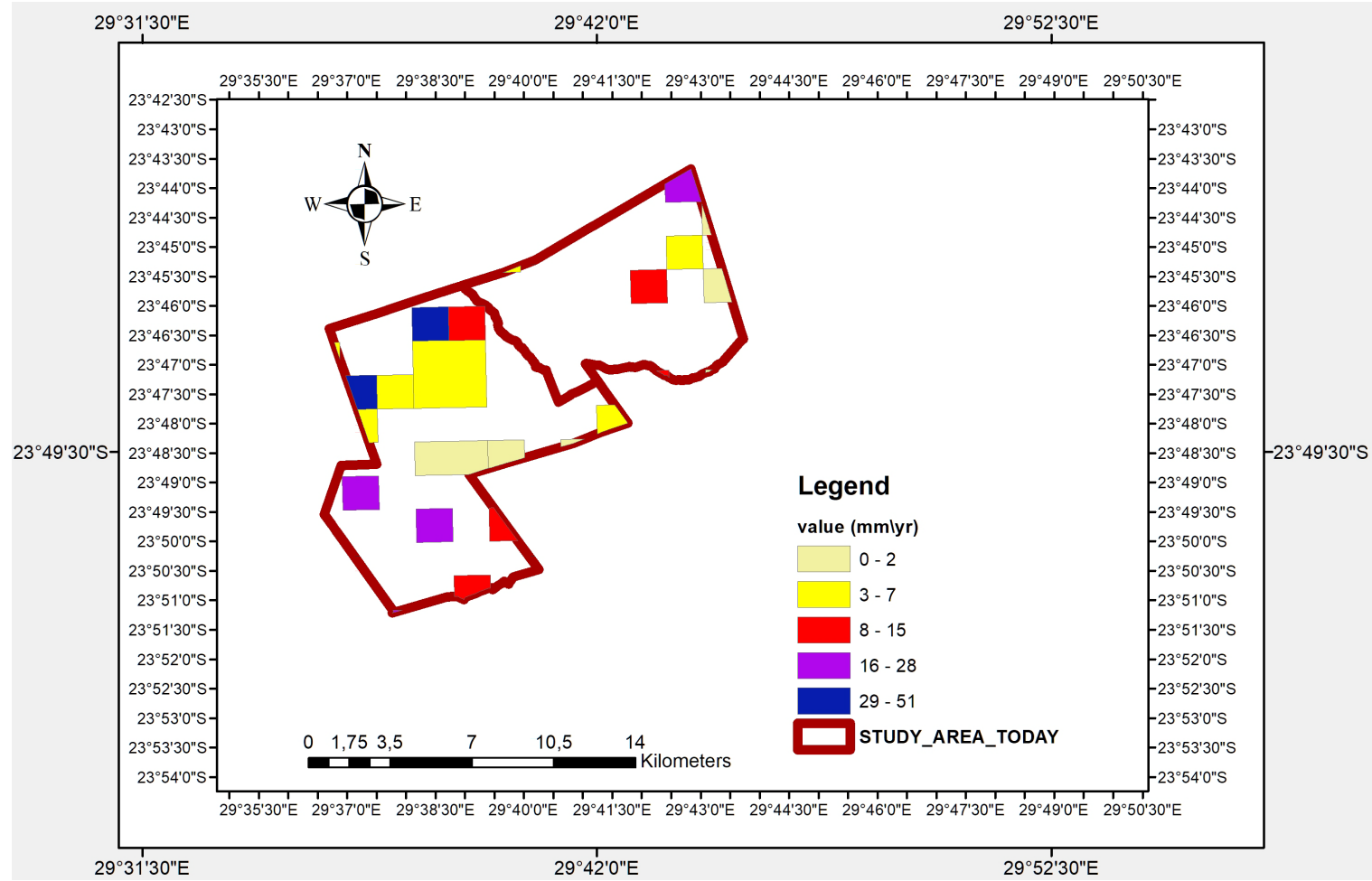

Figure 8. Groundwater recharge map of Makotopong village.

balance residual raster for the study area. Each cell value denotes the groundwater bulk steadiness residual for balanced flow in an aquifer, as resolute by Dar- 
cy's Law in ArcGIS tool. Table 2 shows the value classes on the groundwater recharge map. Figure 9 shows the calculated mean average groundwater recharge value for the study area.

A comparison was done on estimated recharge of the study with results of previous researchers. Table 3 shows the comparison of estimated recharge results with previous studies. The mean annual recharge values were obtained by defining the same areas within the study area from the South African recharge maps using ArcGIS.

The estimation of groundwater recharge using Chlorine mass balance (CMB) method was done by [11] and resulted in a mean annual recharge value of 8 $\mathrm{mm}$ /year. The same method was used by Holland in 2011 and resulted in a recharge value of $4 \mathrm{~mm} /$ year. Holland also used Water-Table Fluctuation method to estimate groundwater recharge and resulted in a value of $12.3 \mathrm{~mm}$ /year. In this study the estimation of groundwater recharge using GIS methods resulted in a mean recharge value of $12.14 \mathrm{~mm} /$ year.

Table 2. Records of calibrated groundwater flow model.

\begin{tabular}{cc}
\hline Recharge Value $(\mathrm{mm} / \mathrm{yr})$ & Value Class \\
\hline $0-2$ & Very Low Recharge \\
$3-7$ & Very Low Recharge \\
$8-15$ & Medium Recharge \\
$16-28$ & Good Recharge \\
$29-51$ & Very Good Recharge \\
\hline
\end{tabular}

Table 3. Comparisons of estimated recharge results with previous studies.

\begin{tabular}{cccc}
\hline Year & Mean annual Recharge & Methods used & Source \\
\hline 1995 & 8 & Chlorine Mass Balance (CMB) & Vegter, 1995 \\
2011 & 4 & Chlorine Mass Balance (CMB) & Holland, 2011 \\
2011 & 12.3 & Water-Table Fluctuation (WTF) & Holland, 2011 \\
2018 & 12.04 & ArcGIS & This study 2018
\end{tabular}

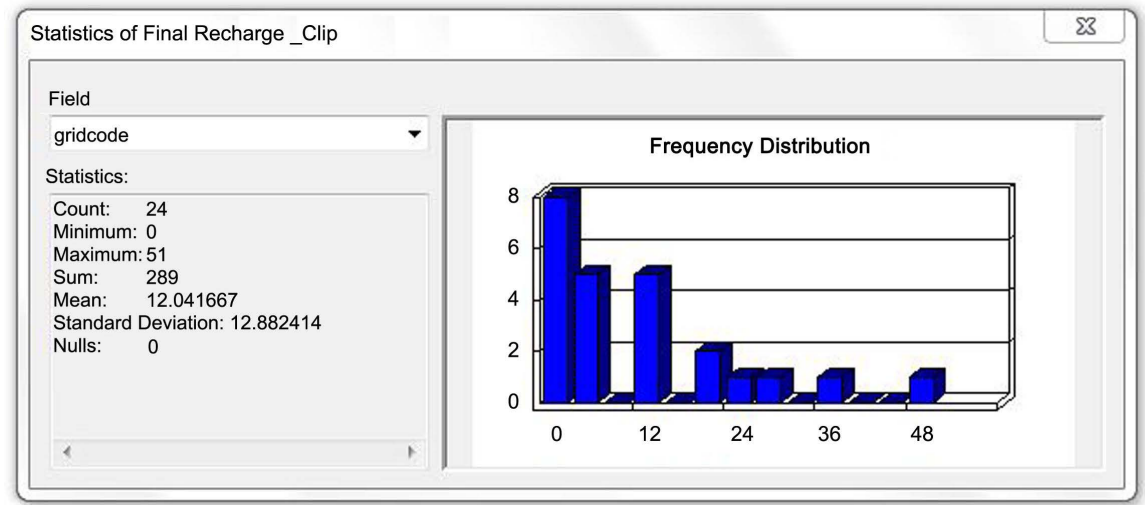

Figure 9. Mean annual groundwater recharge values. 


\section{Model Calibration}

Groundwater flow models are usually calibrated to Head dimensions at designated observation points. Figure 10 shows the distribution of observation wells that were used for model calibration. During calibration process, model inputs such as parameter values used to quantify physical properties, initial and boundary conditions are modified so that the model output matches related measured values. In this study observation points were identified for the calibration process and heads measured from the groundwater level were used as calibration values. During the calibration process, Hydraulic Conductivities were estimated initially using trial and error method to obtain reasonable fit of groundwater levels.

The standards used in this study were acquired from [12] indicating that, for Mean Absolute Error (MAE), the collective effect should not be more than 10 meters difference between the observed and calculated heads and, Normalizes Root Mean Square (NRMS) should be less or equal to $10 \%$. This is because NRMS is a good illustrative acceptable measure than the standard RMS, as it accounts for the measure of potential range of statistics values. The initial conductivity value for the study area was 0.2 and the calibrated value was 0.009 . The achieved calibrated value was used to calculate the statistics being 1) ME 2) MAE 3) RMSE and 4) NRMS.

The results from calibrated groundwater flow model produced satisfactory calibration figures related to target criteria. Calibration statistics are specified in Table 4. The normalized Root mean square (NRMS) was $8.405 \%$, while the Mean error (ME) and Mean absolute error (MAE) were within the set criteria.

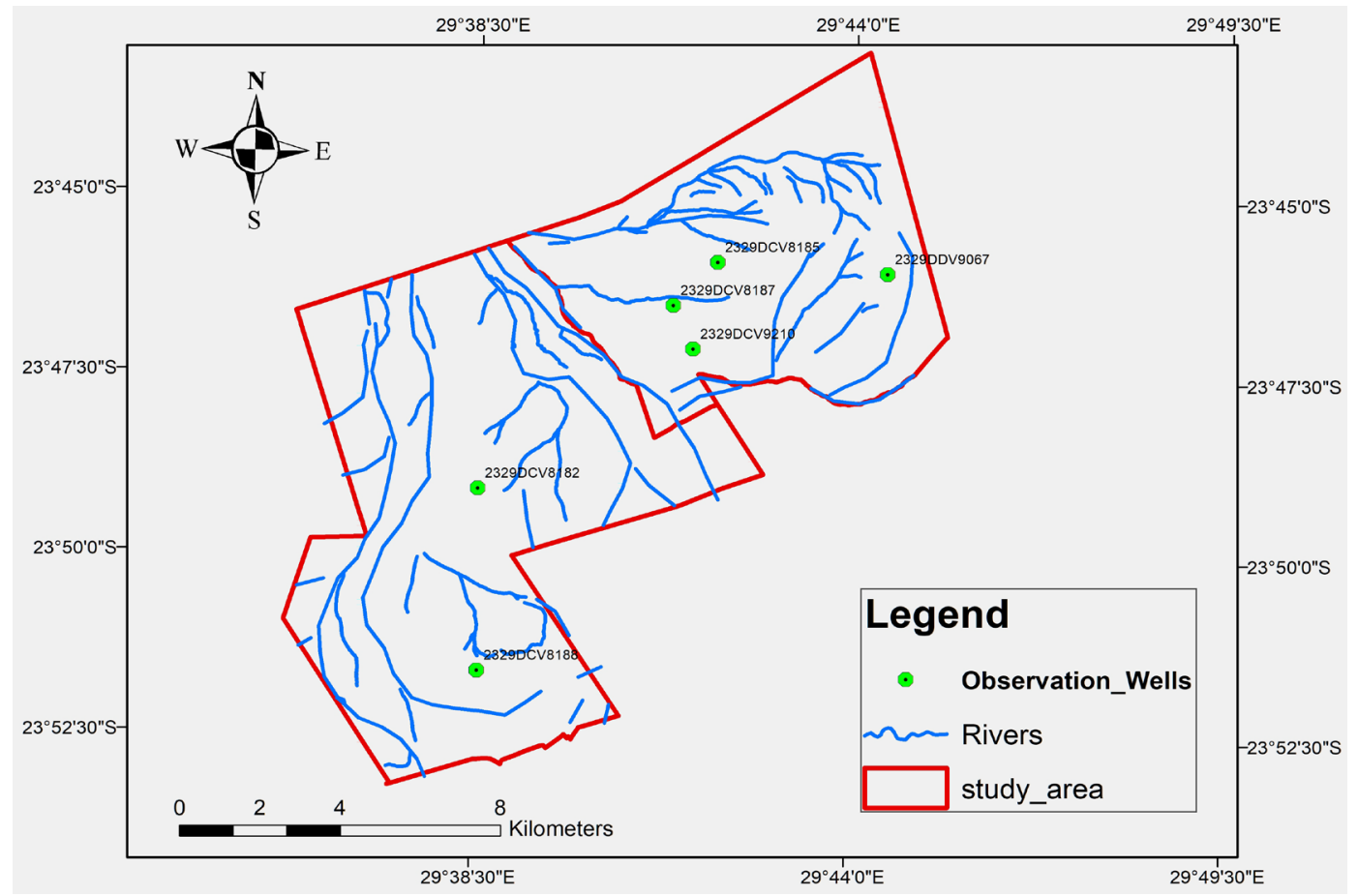

Figure 10. Distribution of observation wells. 
Table 4. Records of calibrated groundwater flow model.

\begin{tabular}{ccc}
\hline Criteria & Criteria Values & Calibration results \\
\hline Normalised Root mean squares (NRMS) & $10 \%$ & $8.405 \%$ \\
Mean Error (ME) & $10 \mathrm{~m}$ & $6.943 \mathrm{~m}$ \\
Mean Absolute Error (MAE) & $\pm 10 \mathrm{~m}$ & $5.034 \mathrm{~m}$ \\
Correlation coefficient (Cor) & 1 & 0.982 \\
\hline
\end{tabular}

The calculated linear coefficient of 0.982 shows optimistic correlation between observed and simulated head values. According to [13], well-calibrated models are anticipated to have linear regression coefficients close to 1 . In this case, the calibrated groundwater model can be said to have been well-calibrated.

Scatter plot graph was plotted to demonstrate the comparison amongst observed and calculated heads at $95 \%$ sureness interval. The scatter plot demonstrates a good scattering of residual around zero. This defines that there is no prejudice in the calibrated values and the information can be used for more analysis of the groundwater flow model. Figure 11 shows the scatter plot graph for calculated head and observed head for the calibration model.

\section{Model Validation}

Groundwater flow model was validated using groundwater levels at 3 monitoring wells. The performance statistics for validated model are shown in Table 5.

The NMRS for validated model was $8.307 \%$ which is slightly less than that of the calibrated model $(8.405 \%)$ by $0.09 \%$. The linear correlation was calculated as 0.988 which was very close to that of the calibrated model. In addition, most of the performance statistics for validation model were within acceptable set criteria.

The scatter plot demonstrates a good scattering of residual around zero as shown in Figure 12, which means that the validated model yielded comparable water elevations for most of the wells. This implies that the validated model can be used for prediction purposes and hence suitable for management of the groundwater aquifer of the study area.

\section{Conclusions}

Estimation of groundwater recharge has been increasingly implemented in previous studies because of high water demand. The estimation of groundwater recharge using GIS methods resulted in a mean recharge value of $12.04 \mathrm{~mm} /$ year which shows a close comparison with previous studies conducted by [11] using Chlorine Mass Balance (CMB) and [4] using Water-Table Fluctuation (WTF). This implies that GIS is a potential tool that can be used to estimate groundwater recharge.

Groundwater recharge values can be useful to engineers in decision making for activities such as designing an optimal sustainable groundwater supply system with appropriate groundwater management resources. As the population 


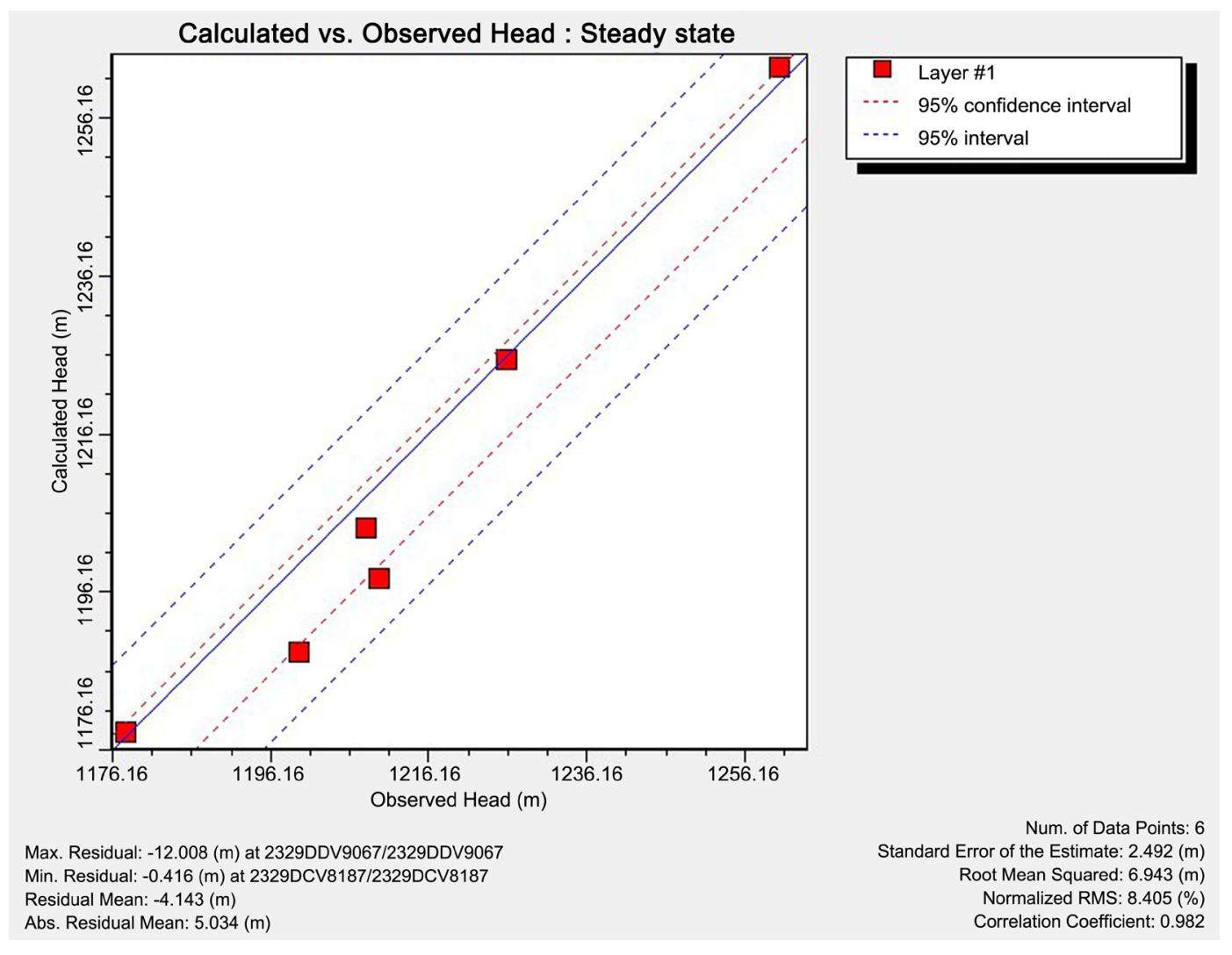

Figure 11. Scatter plot graph for calculated versus observed head.

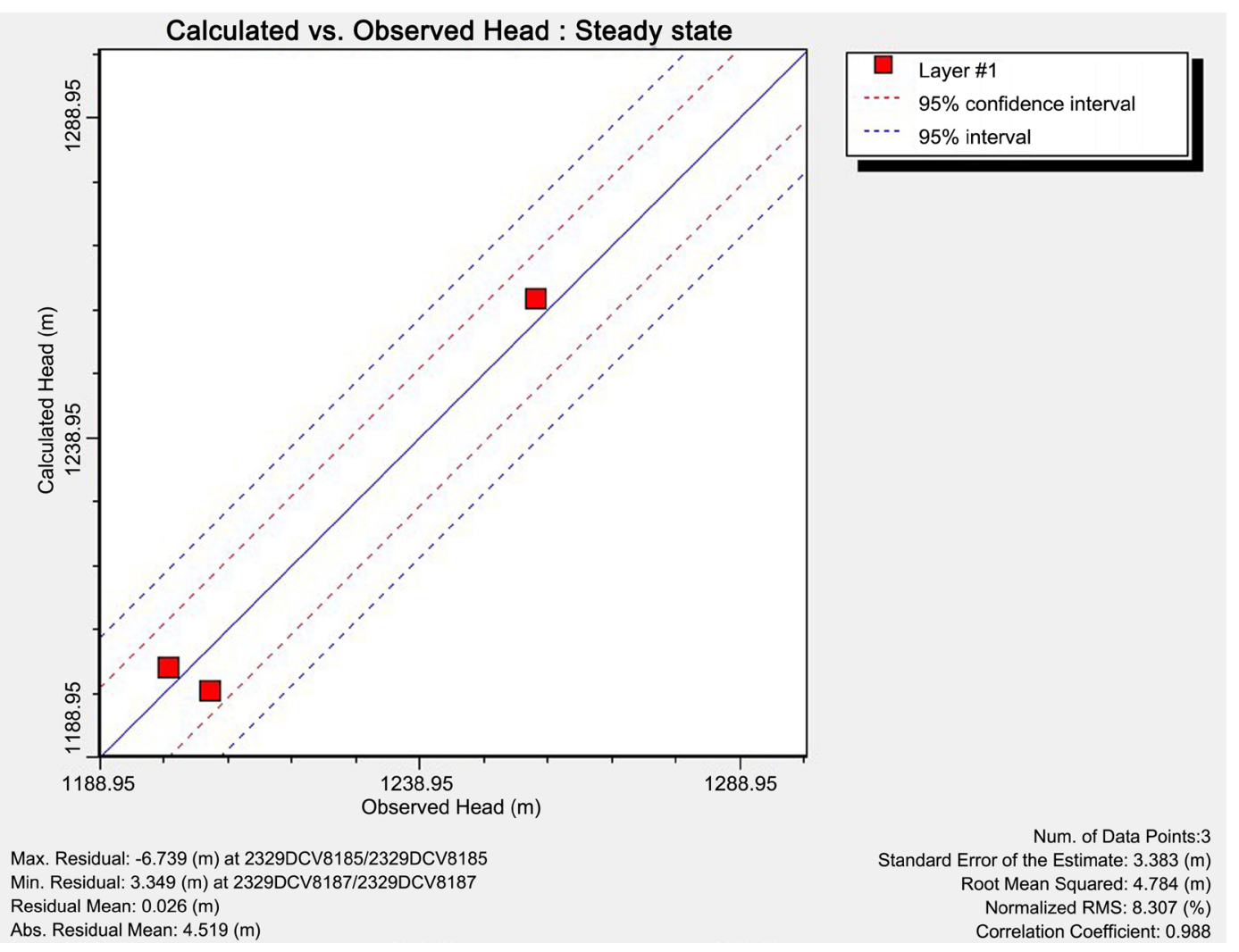

Figure 12. Scatter plot graph for calculated versus observed head. 
Table 5. Records of calibrated groundwater flow model.

\begin{tabular}{ccc}
\hline Criteria & Criteria Values & Pest results \\
\hline Normalised Root mean squares (NRMS) & $10 \%$ & $8.307 \%$ \\
Mean Error (ME) & $10 \mathrm{~m}$ & $3.383 \mathrm{~m}$ \\
Mean absolute error (MAE) & $10 \mathrm{~m}$ & $4.784 \mathrm{~m}$ \\
Correlation coefficient (Cor) & 1 & 0.988 \\
\hline
\end{tabular}

increases annually, it is therefore necessary to evaluate possible future water demand. These results also help planners to properly plan for future water supply.

\section{Conflicts of Interest}

The authors declare no conflicts of interest regarding the publications of this journal paper.

\section{References}

[1] Ahlfeld, D.P., Baker, K.M. and Barlow, P.M. (2009) GWM-2005 A Groundwater-Management Process for MODFLOW-2005 with Local Grid Refinement (LGR) Capability. U.S. Geological Survey, Techniques and Methods 6-A33, 65 p. https://doi.org/10.3133/tm6A33

[2] Holland, M. (2011) Hydrogeological Characterisation of Crystalline Basement Aquifers within the Limpopo Province, South Africa. Doctoral Dissertation, University of Pretoria, Pretoria.

[3] Rwanga, S.S. (2013) A Review on Groundwater Recharge Estimation Using Wetspass Model. International Conference on Civil and Environmental Engineering, (CEE), Johannesburg, 27-28 November 2013, 156.

[4] Sami, K., Neumann, I., Gquiba, D., de Kock, G. and Grantham, G. (2002) Groundwater Exploration in Geologically Complex and Problematic Terrain-Case Studies (Volume 2).

[5] Nemaxwi, P., Odiyo, J. and Makungo, R. (2019) Estimation of Groundwater Recharge Response from Rainfall Events in a Semi-Arid Fractured Aquifer: Case Study of Quaternary Catchment A91H, Limpopo Province, South Africa. Cogent Engineering, 6, 1635815. https://doi.org/10.1080/23311916.2019.1635815

[6] Singh, A., Panda, S., Kumar, K. and Sharma, C. S. (2013) Artificial Groundwater Recharge Zones Mapping Using Remote Sensing and GIS: A Case Study in Indian Punjab. Environmental Management, 52, 61-71. https://doi.org/10.1007/s00267-013-0101-1

[7] South African Weather Service (2017) Temperatures and Rainfall Data.

[8] FAO (2005) Digital Soil Map of the World and Derived Soil Properties of the World. Food and Agricultural Organization of the United Nations.

[9] Rahman, A. (2008) A GIS based DRASTIC Model for Assessing Groundwater Vulnerability in Shallow Aquifer in Aligarh, India. Applied Geography, 28, 32-53. https://doi.org/10.1016/j.apgeog.2007.07.008

[10] Bear, J. (2012) Hydraulics of Groundwater. Courier Corporation, Mineola, New York.

[11] Vegter, J. (1995) Groundwater Resources of South Africa. An Explanation of a Set 
of National Groundwater Maps. Water Research Commission, Pretoria

[12] Willmott, C. J. and Matsuura, K. (2005) Advantages of the Mean Absolute Error (MAE) over the Root Mean Square Error (RMSE) in Assessing Average Model Performance. Climate Research, 30, 79-82. https://doi.org/10.3354/cr030079

[13] Zheng, C. and Bennett, G.D. (2002) Applied Contaminant Transport Modeling. Wiley-Interscience, New York. 